Dhaka Univ. J. Biol. Sci. 26(2): 167-174, 2017 (July)

\title{
IDENTIFICATION AND COMPARISON OF THREE CARP FISHES BASED ON MITOCHONDRIAL 16S rRNA GENE
}

\author{
Hawa Jahan, Maria Akter, Rowshan Ara Begum* \\ AND REZA MD SHAHJAHAN \\ Department of Zoology, University of Dhaka, Dhaka-1000, Bangladesh \\ Key words: Three carp fishes, PCR-sequencing, 16S rRNA
}

\begin{abstract}
Identification of Labeo rohita, L. bata and L. gonius is sometimes problematic when usual morphological features are lost and it is difficult to differentiate them with traditional morphological features at their diverse developmental stages. PCR-sequencing provides an authentic alternative means of identification of individuals at species level. Three local carp fishes were collected and 16S rRNA genes were sequenced by sanger sequencing method after PCR amplification using universal primers. Obtained sequences were found accurate with blast search result which showed maximum range of similarity with the existing respective gene fragments present in GenBank database. Sequences were compared and multiple sequence alignment has revealed some polymorphic sites which can be used to differentiate these three species from one another. This study may provide valuable understanding to study their population in future.
\end{abstract}

\section{Introduction}

Bangladesh is very rich of diverse and exclusive fish fauna, because it is a land of vast and highly diverse water resources. It is thought that in freshwater genetic diversity, Bangladesh is one of the richest countries in the world. Carps are of freshwater fish of the family Cyprinidae belongs to order Cypriniformes, a large group of fish native to Europe and Asia. The family Cyprinidae is the most diverse family of freshwater fishes in the world.

Fish species identification is traditionally based on external morphological features, including body shape, presentation of colors, scale size and count, number and relative position of fins, number and variety of fin rays, or various proportionate measurements of body parts ${ }^{(1)}$. Yet, in some cases morphological features are of constricted value for identification and differentiation purposes, even with intact specimens, because they can show either significant intraspecific variations or little differences between species. Besides, once most morphological features have been separated, the identification becomes difficult or even impossible. Furthermore, the identification of early life stages

*Author for correspondence: <rowshanbegumdu@yahoo.com>. 
(egg and larvae) is even more complicated than adult identification ${ }^{(2)}$. That is why researchers have attempted to develop new methods for identifying fish species without relying on morphological features.

Separation and characterization of specific proteins using electrophoretic techniques was another conventional method used in species identification. As an alternative to protein analysis, DNA-based identification methods have been developed, mainly in the past decade(3). DNA presents several advantages over protein analysis as DNA is more resistant and thermostable than proteins even though it might be altered by various processing and it is still possible to polymerase chain reaction (PCR) amplify small DNA fragments with sufficient information to allow identification. Besides, DNA could potentially be retrieved from any substrate because it is present in almost all cells of an organism such as muscle, fin, or blood.

Because of the high rate of evolution, mitochondrial DNA is an extremely useful molecule for high resolution analysis of evolutionary processes ${ }^{(4)}$. In the past two decades, the mitochondrial 16S rRNA gene has been widely used to explore the phylogenetic relationships of fishes at varying taxonomic levels, e.g. at the order ${ }^{(5)}$, family(6), subfamily ${ }^{(7)}$, genus and species level ${ }^{(8)}$. Therefore, the $16 \mathrm{~S}$ rRNA gene has great potential for the inference of divergences among the cyprinid lineages and resolution of relationships within Cyprininae. Since the structure of $16 \mathrm{~S}$ rRNA gene is highly conserved among the animal taxa that are related even distantly ${ }^{(9)}$, change of even a few nucleotides in such a gene between closely related taxa might indicate a substantial degree of genetic divergence ${ }^{(10)}$. mtDNA sequences have been used as useful marker for species-specific identification in many fishes ${ }^{(11-13)}$.

Cyprinid fishes are nearly world-wide in distribution and contain many culturally and economically important species. The enormous diversity of this group has resulted in many systematic studies, yet no investigation has been examined the monophyly of or the phylogenetic relationships among the species of this group. By investigating information about their genetic relatedness, proper marker can be produced. Their genetic information at molecular level will be helpful in future study of population genetics.

\section{Material and Methods}

Sample collection and identification: Fresh specimens of three carp fishes, Rohu (Labeo rohita), Bata (Labeo bata) and Kuria (Labeo gonius), were collected from a local market of Dhaka. The samples were placed in ice immediately after collection and transferred into $90 \%$ ethanol at $4^{\circ} \mathrm{C}$ after returning to the laboratory. All the specimens were identified morphologically according to the taxonomic key and morphometric and meristic measurements were done. Approximately $45 \mathrm{mg}$ of soft muscle tissue from each 
specimen was collected for extraction of DNA and rest was preserved as voucher specimen.

DNA extraction: Total genomic DNA was extracted by phenol: chloroform extraction method ${ }^{(14)}$ with slight modification. According to the protocol, the fresh specimens were dissected after measuring length and weight to collect the required tissue sample. Samples were squashed in $500 \mu \mathrm{CTAB}$ buffer. $10 \mu \mathrm{l}$ proteinase $\mathrm{K}$ was added and the sample mixture was inverted to mix properly. An equal volume of phenol: chloroform was added to the sample mixture. The mixture was spun again at 13,000 rpm at room temperature for 5 minutes and lower phenol-chloroform phase was removed. DNA is found at the upper aqueous phase. Sample was precipitated with 1 volume of $100 \%$ ethanol at room temperature and inverted several times. DNA was pelleted by centrifugation at $13000 \mathrm{rpm}$ for 5 minutes and washed with $70 \%$ alcohol, dried and dissolved $50 \mu \mathrm{l}$ sterilized distilled water for 10 minutes. The extracted DNA was then visualized in $1.5 \%$ agarose gel of a low melting point grade at $120 \mathrm{~V}$ for 20 minutes. The extracted DNA samples were added to wells constructed in the gel, along with a loading dye (Bromophenol Blue) in a $5: 1$ ratio.

DNA amplification: DNA fragments encoding the $16 \mathrm{~S}$ rRNA gene were amplified by PCR. The chemicals used for the amplification of mitochondrial DNA were $2 \mu \mathrm{l}$ of 10X PCR reaction buffer, $1.6 \mu \mathrm{l}$ of $25 \mathrm{mM} \mathrm{MgCl}_{2}, 0.5 \mu \mathrm{l}$ of $10 \mathrm{mM}$ dNTP, $0.5 \mu \mathrm{l}$ of $16 \mathrm{~S}$ rRNA forward primer 16S rRNA-F (5'-CGCCTGTTTAACAAA AACAT-3'), $0.5 \mu l$ of 16S rRNA reverse primer $16 \mathrm{~S}$ rRNA-R (5'-CCGGTTTGAACTCAGA TCATGT-3'), $0.16 \mu l$ of taq polymerase, $2 \mu \mathrm{l}$ template DNA, and sterilized distilled water is used to make up a total volume of $25 \mu \mathrm{l}$. Amplifying conditions were $93^{\circ} \mathrm{C}$ for $60 \mathrm{~s}$ in denaturation, $53^{\circ} \mathrm{C}$ for $90 \mathrm{~s}$ in annealing, and $72^{\circ} \mathrm{C}$ for $90 \mathrm{~s}$ in extension for 30 cycles with a final polymerization step at $72^{\circ} \mathrm{C}$ for 5 minutes. PCR products were resolved by electrophoresis in a $1.5 \%$ agarose gel of a low melting point grade, amplified DNA samples were added to wells constructed in the gel, along with a loading dye (Bromophenol blue) in a 5:1 ratio and stained with ethidium bromide to visualize DNA bands. Dilution of the template DNA is required because the isolated DNA was highly concentrated and unsuitable for using in PCR. DNA template was diluted with sterilized distilled water in a ratio of $1: 9$. For the dilution of the primer equal volume of sterilized distilled water was added to the tube as its molecular weight. The universal primer set ${ }^{15)}$ was used in the amplification of the DNA fragments for all the specimens. The PCR products of interest were then purified using Favor Prep PCR Clean up Mini Kit (Favorgen Biotech Corp.) and then washed in $70 \%$ ethanol dried and re-suspended in $50 \mu \mathrm{l}$ of sterilized distilled water.

$16 S$ rRNA sequencing: After the amplified DNA samples were purified successfully, their sequences were determined by Sanger Dideoxy Sequencing method in Centre for Advanced Research in Sciences (CARS), University of Dhaka, Dhaka. 


\section{Results and Discussion}

Carp fishes were morphologically identified according to the taxonomic keys ${ }^{(16)}$ for all the collected fish specimens to ensure proper taxonomic identification. A detailed morphometric and meristic study was performed (Table 1) where average body measurements, average head measurements, average fin base length, average number of fin rays or spines were the basic parameters of measurements. Fish species taxonomy is traditionally based on morphological and anatomical traits. Yet reliance on morphology can sometimes present difficulties in cases where species may be very similar morphologically or apparent differences are misleading ${ }^{(17)}$. Therefore, the reconstructed phylogenetic trees based on morphology were controversial due to the complex evolutionary changes in either morphological or physiological characters. Recent advances in molecular biology have changed this situation. Recently, the genetic analysis of mtDNA has been conducted to resolve the controversial taxonomic problem ${ }^{(18)}$ and has proved that molecular markers can facilitate the discrimination of morphologically similar species ${ }^{(19)}$.

DNA extraction was done by above mentioned method where a good yield of total genomic DNA of high molecular weight found. DNA molecule remained intact and as it was RNase and proteinase $\mathrm{K}$ treated, it was RNA free and comparatively pure. The concentration was also suitable for future application in PCR. DNA obtained by this method was subjected to agarose gel electrophoresis and specific bands were observed (Fig. 1A).The extracted DNAs found from studied fishes were amplified by PCR amplification of mitochondrial $16 \mathrm{~S}$ rRNA gene using universal primer and $1.5 \%$ agarose gel showed clear band of each with product size of around $600 \mathrm{bp}$ (Fig. 1B).

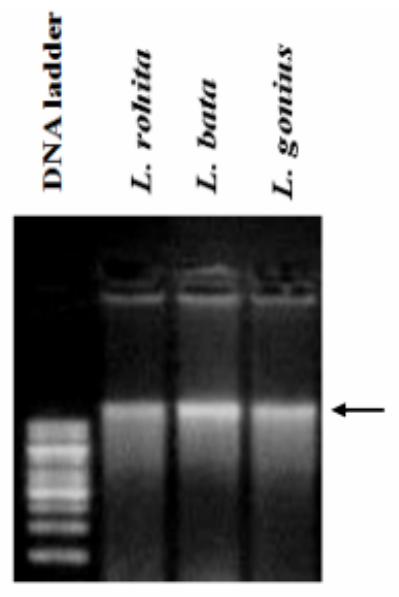

(A)

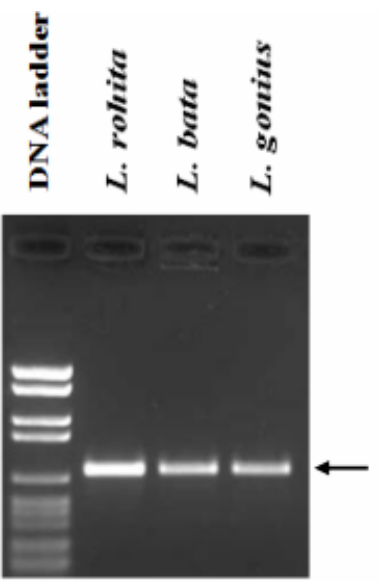

(B)

Fig. 1. Images of agarose gel electrophoresis for extracted DNA of L. rohita, L. bata and L. gonius (A), 16S rRNA primer based PCR (B). 


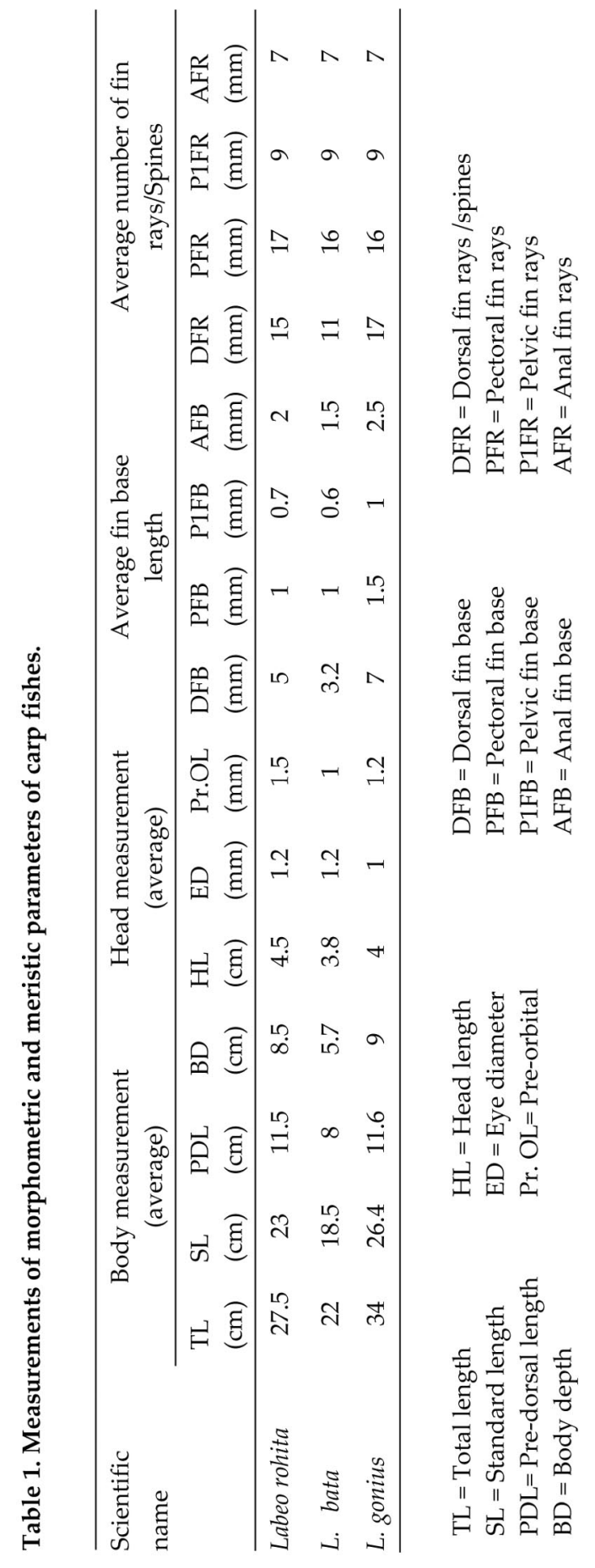


The mitochondrial $16 \mathrm{~S}$ rRNA region of all samples was successfully sequenced by the Sanger sequencing method. Both the forward and reverse primers were used in the sequencing and the sequences found from both ends of the DNA were mostly identical. Only the identical portions (around 400bp) of sequence data were transferred to FASTA format and BLASTED within nucleotide database for the authentication of the morphological identification and the database revealed definitive identity matches in the range of $97 \%-99 \%$ for consensus sequences of three species. GenBank-based identification for all species yielded an alignment E-value of 0.0. Molecular identifications supported the morphological ones. A variety a DNA based methods are potentially available for use in fish species identification. These vary in their range of applications, complexity and costs (17). Application of molecular tools can provide valuable information for species identification and can complement the traditional taxonomic data.

Mitochondrial gene, such as, cytochrome oxidase I (COI), 16S and 12S rRNA genes are commonly used markers for molecular species identification ${ }^{20,21)}$. According to Guha et al. in a study, 16S rRNA gene has been reported to have a larger number of speciesspecific polymorphic sites compared to the cytochrome $b$ gene indicating the usefulness of $16 \mathrm{~S}$ rRNA gene for species identification(22).

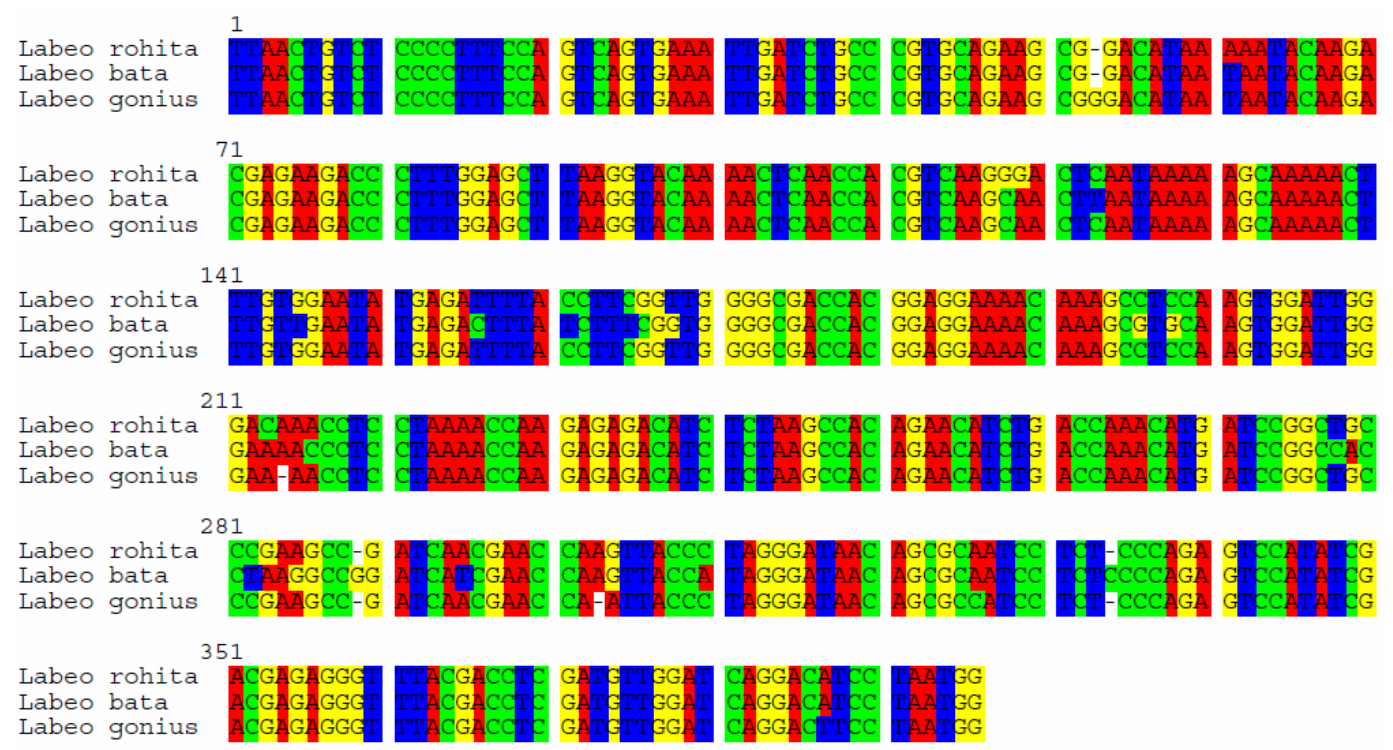

Fig. 2. Multiple sequence alignment of Labeo spp. based on16S rRNA gene fragments.

To compare the sequences obtained, multiple sequence alignment was performed using seaview software where 23 polymorphic sites were identified in around $400 \mathrm{bp}$ sequence (Fig. 2). Mitochondrial 16S rRNA gene can be considered as highly conserved one in case of this fish group. According to Cawthorn et al., among the mitochondrial genes, 16S rRNA gene has been more suitable because it is highly conserved among the vertebrates and has lower sequence variation among the populations of same species ${ }^{(20)}$. 
Based on the revealed polymorphic sites, these carp fishes can be distinguished from one another.

\section{Conclusion}

Using present information, a better understanding of population structure of carp fishes will be obtained and this will be great important for good management and conservation of this valuable resource. Additional steps can be taken for experimental traits on extensive farming system of these fishes. By obtaining their genetic information, conservation and management of our local species can be possible and the information may be of help to accelerate their breeding programs as well.

\section{Acknowledgment}

The authors would like to thank the authority of the Biotechnology Research Center, Dhaka, Bangladesh for partial funding of this research work.

\section{References}

1. Strange R and C Stepien 2007. Yellow (Perca flavescens) and Eurasian (P. fluviatilis) perch distinguished in fried fish samples by DNA analysis. Fish Bull. 105: 292-295.

2. Smith P, S Cveagh and V Allain 2005. DNA identification of gut contents of large pelagic fishes. J. Fish Biol. 67: 1178-1183.

3. Teletchea T, C Maudet and C Ha"nni 2005. Food and forensic molecular identification: update and challenges. Trends Biotech. 23: 359-366.

4. Brown WM, G Matthew and AC Wilson. 1979. Rapid evolution of animal mitochondrial DNA. Proceedings of the National Academy of Sciences, USA 76: 1967-1971.

5. Ortı', G. and A. Meyer. 1997. The radiation of Characiform fishes and the limits of resolution of mitochondrial ribosomal DNA sequences. Systematic Biology 46: 75-100.

6. Waters JM, JA Lopez and GP Wallis 2000. Molecular phylogenetics and biogeography of galaxiid fishes (Osteichthyes: Galaxiidae): dispersal, vicariance and the position of Lepidogalaxias salamandroides. Systematic Biology 49: 777-795.

7. Harris PH and RL Mayden 2001. Phylogenetic relationships of major clades of Catostomidae (Teleostei: Cypriniformes) as inferred from mitochondrial SSU and LSU rDNA sequences. Molecular Phylogenetics and Evolution 20: 225-237.

8. Chakraborty A and Y Iwatsuki 2006. Genetic variation at the mitochondrial 16S rRNA gene among Trichiurus lepturus (Teleostei:Trichiuridae) from various localities: Preliminary evidence of a new species from West Coast of Africa. Hydrobiologia 563: 501-513.

9. Meyers RA 2000. Encyclopedia of Analytical Chemistry: Applications, Theory, and Instrumentation. John Wiley and Sons, Ltd.

10. Avise JC, GS Helfman, NC Saunders and LS Hales 1986. Mitochondrial DNA differentiation in North Atlantic eels: Population genetic consequences of an unusual life history pattern. Proceeding of the National Academy Science, USA 83(12): 4350-4354. 
11. Chow $S$ and $S$ Inoue 1993. Intra- and interspecific restriction fragment length polymorphism in mitochondrial genes of Thunnus tuna species. Bulletin of National Research Institute of Far Seas Fisheries 30: 229-248.

12. Finnerty JR and BA Block 1992. Direct sequencing of mitochondrial DNA detects highly divergent haplotypes in blue marlin (Makaira nigricans). Molecular Marine Biology and Biotechnology 1(3): 206-214.

13. Hare JA, RK Crown JP Zehr, F Juanes and KH Day 1998. A correction to: Biological and oceanographic insights from larval labrid (Pisces: Labridae) identification using mtDNA sequences. Marine Biology 130 (4): 589-592.

14. Begum RA, T Yamaguchi and W Shugo 2004. Molecular phylogeny of thoracican barnacles based on the mitochondrial $12 \mathrm{~S}$ and $16 \mathrm{~S}$ rRNA genes. Sessile Organisms 21(2): 47-54.

15. Kocher TD, WK Thomas, A Meyer, SV Edwards, S Paabo, FX Villablansca and AC Wilson 1989. Dynamics of mitochondrial DNA evolution in animals: amplification and sequencing with conserved primers. Proceedings of the National Academy of Sciences, USA 86: 6196-6200.

16. Rahman AKA 1989. Freshwater Fishes of Bangladesh. Zoological Society of Bangladesh. pp. 161171.

17. Fabrice T 2009. Molecular identification methods of fish species: reassessment and possible applications. Rev. Fish Biol. Fisheries 19: 265-293.

18. Ruber LR, R Britz and YR Zardoya 2006. Molecular phylogenetics and evolutionary diversification of labyrinth fishes (Perciformes; Anabantoidei). Systematic Biolology 55: 374-397.

19. Erguden D, M Gurlek, D Yaglioglu and C Turan 2010. Genetic identification and taxonomic relationship of Mediterranean Mugilid Species Based on Mitochondrial 16S rDNA Sequence Data. J. Ani. Veter. Adv. 9: 336-341.

20. Cawthorn DM, HA Steinman and RC Witthuhn 2012. Evaluation of the $16 \mathrm{~S}$ and $12 \mathrm{~S}$ rRNA genes as universal markers for the identification of commercial fish species in South Africa. Gene 491(1): 40-48.

21. Di Finizio A, G Guerriero, GL Russo and G Ciarcia 2007. Identification of gadoid species (Pisces, Gadidae) by sequencing and PCR-RFLP analysis of mitochondrial $12 \mathrm{~S}$ and $16 \mathrm{~S}$ rRNA gene fragments. European Food Research and Technology 225 (3): 337-344.

22. Guha S, SP Goyal and VK Kashyap 2006. Genomic variation in the mitochondrially encoded cytochrome b (MT-CYB) and 16S rRNA (MT-RNA2) genes: Characterization of eight endangered Pecoran species. Anim Genet. 37(3): 262-265.

(Manuscript received on 1 June, 2017; revised on 16 July, 2017) 